\title{
A Novel Nickel(II) Complex with 1,4-Dithia-8,11-diazacyclotetradecane Derivative as a Structural Model of the Nickel Site in [FeNi]-Hydrogenases
}

\author{
Z. Zhang, ${ }^{1,2}$ H. Kanamori, ${ }^{2}$ T. Ozawa, ${ }^{2}$ K. Jitsukawa, ${ }^{2}$ H. Masuda, ${ }^{2}$ and L. Zhang $^{1 *}$ \\ ${ }^{1}$ The Key Laboratory of Beijing City on Preparation and Processing of Novel Polymer Materials, Beijing University of \\ Chemical Technology, Box 57, Beijing 100029, People's Republic of China \\ ${ }^{2}$ Graduate School of Material Science and Engineering, Nagoya Institute of Technology, Showa-ku, Nagoya 466-8555, \\ Japan \\ Fax:+81-52-735-5209, e-mail: masuda.hideki@nitech.ac.jp
}

\begin{abstract}
A new Ni(II) complex with 8-(2-pylidylmethyl)-1,4-dithia-8,11-diazacyclotetradecane ligand ( $\left.\mathrm{P}[14] \mathrm{ane} \mathrm{N}_{2} \mathrm{~S}_{2}\right)$, [NiP[14]ane $\left.\mathrm{N}_{2} \mathrm{~S}_{2}\left(\mathrm{H}_{2} \mathrm{O}\right)\right]\left(\mathrm{ClO}_{4}\right)_{2}$ (1), was prepared as a structural model of [FeNi] hydrogenase active site. The $\mathrm{X}$-ray crystal structure analysis of the complex, in which the coordinated water molecule was replaced by $\mathrm{Br}^{-}$, revealed an octahedral geometry coordinated with $\mathrm{P}[14] \mathrm{aneN}_{2} \mathrm{~S}_{2}$ and $\mathrm{Br}^{-}$. The cyclic voltammograms of complex 1 gave only a reversible wave of $\mathrm{Ni}^{2+/+}$ couple at $E_{1 / 2}=-920$ $\mathrm{mV}$ vs. SCE in $\mathrm{MeOH}$ and two reversible waves of $\mathrm{Ni}^{2+/+}$ and $\mathrm{Ni}^{3+/ 2+}$ couples at $E_{1 / 2}=-970$ and $1350 \mathrm{mV}$ vs. SCE in MeCN, respectively, indicating that complex 1 can take a wide range of oxidation states of nickel ion. The reduction of complex 1 with $\mathrm{NaBH}_{4}$ in $\mathrm{MeOH}$ at $-20^{\circ} \mathrm{C}$ gave the $\mathrm{Ni}(\mathrm{I})$ complex with a hydride ion at the axial position, which was demonstrated by ESR spectroscopy.
\end{abstract}

Key words: [FeNi] hydrogenase, Nickel(II) complex, ESR, Hydride

\section{INTRODUCTION}

[FeNi] Hydrogenases [1] are metalloenzymes that catalyze the reversible two-electron oxidation of dihydrogen $\left(\mathrm{H}_{2} \rightleftarrows 2 \mathrm{H}^{+}+2 \mathrm{e}-\right)$ and are involved in the production and consumption of $\mathrm{H}_{2}$ by various microorganisms, in which the $\mathrm{Ni}$ site is considered to play as the active center for the uptake and oxidation of $\mathrm{H}_{2}$. Recently the X-ray crystal structures of [FeNi] hydrogenases isolated from Desulfovibrio gigas [2a] and Desulfovibrio vulgaris Miyazaki [2b] revealed that the Ni site is penta-coordinated with four thiolate sulfurs of cystein residues and one $\mathrm{S} / \mathrm{O}$ atom. X-ray absorption spectroscopy of the [FeNi] hydrogenase from the purple photosynthetic bacterium Thiocapsa roseopersicina indicated that the active nickel center exists most probably in either trigonal bipyramidal or six-coordinate with $2 \pm 1 \mathrm{~S}(\mathrm{Cl})$-donor ligands at $2.23 \pm 0.03 \AA$ and $3 \pm 1 \mathrm{~N}(\mathrm{O})$-donor ligands at $2.00 \pm 0.06$ A..[3] ESR study of the [FeNi] hydrogenase indicated the spectral behaviors suggesting that the Ni site goes through three different redox states of $\mathrm{Ni}(\mathrm{I}), \mathrm{Ni}(\mathrm{II})$, and $\mathrm{Ni}(\mathrm{III})$.[1 $1 \mathrm{c}]$ [FeNi] hydrogenase isolated from Desulfovibrio gigas under air, which is in fully oxidized and enzymatically inactive states, displayed two kinds of rhombic ESR signals; Ni-A form (an unready state) $(\mathrm{g}=2.31,2.23$, and 2.02) and Ni-B form (a ready state) $(\mathrm{g}=2.33,2.16$, and
2.02).[1] The oxidized forms under $\mathrm{H}_{2}$ atmosphere were ESR silent. Additional exposure of $\mathrm{H}_{2}$ to the hydrogenase resulted in appearance of another rhombic ESR signals of $\mathrm{Ni}-\mathrm{C}$ form ( $\mathrm{g}=2.19,2.14$, and 2.01) which is enzymatically active.[1] Extensive incubation of the enzyme under $\mathrm{H}_{2}$ led to formation of the fully reduced form (R). The Ni-C form has been deduced to be in the $\mathrm{Ni}(\mathrm{III})$ or $\mathrm{Ni}(\mathrm{I})$ state coordinated with $\mathrm{H}^{-}$or $\mathrm{H}_{2}$ on the basis of the results of ESR and ENDOR experiments.[1,4] This Ni-C form has also been supported to be in the $\mathrm{Ni}(\mathrm{I})$ state, $[1,5]$ because it reversibly reacts with CO.

Recently, with the aim of making clear some problems such as the oxidation states of the nickel center, coordination of $\mathrm{H}^{-} / \mathrm{H}_{2}$, redox properties of nickel ion, and so on, many structural and/or functional model studies have been carried out by use of the nickel complexes with sulfur atoms as coordination sites for hydrogen.[6,7,8] We are also interested in constructing the model complex having these coordination features, and we newly synthesized the Ni(II) complex of 8-(2-pyridylmethyl)-1,4-ditha-8,11-diazacyclotetradecane (P[14]ane $\mathrm{N}_{2} \mathrm{~S}_{2}$; Scheme I).

Here, we will describe the structural characterization and electrochemical property and also the reaction of the complex with some reductants useful for understanding the function 
of the hydrogenases.

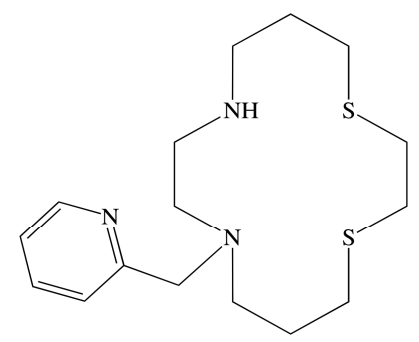

Scheme I. Ligand $\mathrm{P}[14] \mathrm{aneN}_{2} \mathrm{~S}_{2}$

\section{EXPERIMENTAL}

2.1 Materials and Measurements.

Reagents and solvents employed were of the highest grade available. All solvents for spectroscopies were purified by further distillation before use. Other chemicals were used without further purification.

Electronic absorption spectra were taken on a JASCO Ubest-35 spectrophotometer. The samples for spectral measurements were prepared in $\mathrm{MeOH}$ and $\mathrm{MeCN}$. Cyclic voltammetric measurements were performed using a Bioanalytical Systems (BAS) CV-1B instrument equipped with a Graphtec X-Y WX2400 chart recorder. A 3-mm diameter glassy-carbon working electrode, a saturated calomel electrode (SCE) as a reference electrode, and a Pt-wire counter electrode were used in a glass cell having a working compartment. All measurements were made at $25{ }^{\circ} \mathrm{C}$ under an argon atmosphere in $\mathrm{MeOH}$ and $\mathrm{MeCN}$ with tetra(n-butyl)ammonium tetrafluoroborate $\left(\begin{array}{lll}0.1 & \mathrm{M})\end{array}\right)$ as a supporting electrolyte at a scan rate of $100 \mathrm{mV} / \mathrm{s}$. X-band ESR spectra of frozen solutions were recorded at $77 \mathrm{~K}$ by using a JEOL RE-1X ESR spectrometer. ESR samples were prepared in $\mathrm{MeOH}$ solution in quartz tubes, and the reactions were performed in the temperature range $-20 \sim 0{ }^{\circ} \mathrm{C}$ under an argon atmosphere. $\mathrm{NaBH}_{4}$ and $\mathrm{Na}_{2} \mathrm{~S}_{2} \mathrm{O}_{4}$ were employed as a reductant. The reductions of complex were carried out by the two methods; (i) addition of 1.2 equiv of $\mathrm{Na}_{2} \mathrm{~S}_{2} \mathrm{O}_{4}$ in $0.1 \mathrm{~mL}$ of $\mathrm{H}_{2} \mathrm{O}$ and (ii) addition of 1.2 equiv of $\mathrm{NaBH}_{4}$ in $0.1 \mathrm{~mL}$ of ethanol. Elemental analyses were performed on a Leco CHN-900 analyzer.

\subsection{Preparations of $\mathrm{P}[14] \mathrm{aneN}_{2} \mathrm{~S}_{2}$ Ligand.}

To a $\mathrm{CH}_{2} \mathrm{Cl}_{2}(100 \mathrm{~mL})$ solution containing [14] ane $\mathrm{N}_{2} \mathrm{~S}_{2}$ [9] $(0.53 \mathrm{~g}, \quad 2.5 \mathrm{mmol})$ and triethylamine $(0.30 \mathrm{~g}, 3 \mathrm{mmol})$ was added a $\mathrm{CH}_{2} \mathrm{Cl}_{2}$ (100 mL) solution of 2-(bromomethyl)pyridine $(0.52 \mathrm{~g}, 3 \mathrm{mmol})$ from a dropping funnel at a rate of about $1 \mathrm{~mL} / \mathrm{min}$. The mixed solution was stirred, whereby the reaction was followed by TLC (silicagel, $\mathrm{CHCl}_{3}-\mathrm{MeOH}(7: 1)$ ). After completing the reaction, the solvent was evaporated off, which were separated by column chromatography on silicagel with $\mathrm{CHCl}_{3}-\mathrm{MeOH}$
(10:1). Yield: $0.16 \mathrm{~g}(0.5 \mathrm{mmol}), 20 \%$.

2.3 Preparation of [NiP $\left.[14] \operatorname{aneN}_{2} \mathrm{~S}_{2}\left(\mathrm{H}_{2} \mathrm{O}\right)\right]$ $\left(\mathrm{ClO}_{4}\right)_{2}(\mathbf{1})$.

Complex 1 was prepared by mixing an $\mathrm{MeOH}$ solution $(5 \mathrm{~mL})$ of $\mathrm{P}[14] \mathrm{aneN}_{2} \mathrm{~S}_{2} \quad(0.16 \mathrm{~g}$, $0.5 \mathrm{mmol})$ and an $\mathrm{MeOH}$ solution $(5 \mathrm{~mL})$ of $\mathrm{Ni}\left(\mathrm{ClO}_{4}\right)_{2} \cdot 6 \mathrm{H}_{2} \mathrm{O} \quad(0.18 \mathrm{mg}, 0.5 \mathrm{mmol})$. Purple plate-like crystals of $\left[\mathrm{NiP}[14] \mathrm{aneN}_{2} \mathrm{~S}_{2}\left(\mathrm{H}_{2} \mathrm{O}\right)\right]-$ $\left(\mathrm{ClO}_{4}\right)_{2}$ were obtained by slow diffusion of hexane into the $\mathrm{MeOH}$ solution of the reaction product. Yield $0.17 \mathrm{~g}(0.3 \mathrm{mmol}), 66 \%$. Anal. Calc. for $\mathrm{C}_{16} \mathrm{H}_{29} \mathrm{Cl}_{2} \mathrm{NiN}_{3} \mathrm{O}_{9} \mathrm{~S}_{2}$ : C, 31.96; $\mathrm{H}, 4.86 ; \mathrm{N}, 6.99$. Found: C, $31.73 \mathrm{H}, 4.77$; N, 6.81 .

Crystal used for X-ray analysis was obtained from the reaction of 1 with $\mathrm{KBr}$ in $\mathrm{MeOH}$ solution.

2.4 X-ray Structure Analyses of Complex 1.

A single crystal of complex 1 was mounted on a glass capillary. The diffraction data were collected with graphite-monochromated Mo-K $\alpha$ radiation on an Enraf-Nonius CAD4-EXPRESS four-circle diffractometer at room temperature with the $\omega-2 \theta$ scan technique. Crystallographic data and experimental details are described in the reference [10].

The structure was solved by a combination of the direct method and the Fourier technique, and they were anisotropically refined for non-hydrogen atoms by full-matrix least-squares calculation. Refinements were continued until all shifts were smaller than one-tenth of the standard deviations of the parameters involved. Atomic scattering factors and anomalous dispersion terms were taken from International Tables for X-Ray Crystallography.[11] Empirical absorption correction was applied after the full isotropic refinement of non-hydrogen atoms. Hydrogen atoms were refined with fixed isotropic temperature coefficients; they were located at the calculated positions. The structure analysis was carried out on an SGI IRIS Indigo XS-24 workstation by using the teXsan program [12] by using the SDP-MolEN program.[13]

\section{RESULTS AND DISCUSSION}

3.1 Solution and Crystal Structures.

The complex $\mathbf{1}$ gave the absorption bands characteristic of a six-coordinate octahedral one [14] in the visible region in both $\mathrm{MeOH}$ and $\mathrm{MeCN} ; 340$ (sh 70), 550 (10), and 860 (10) in $\mathrm{MeOH}$ and 335 (sh 90), 525 (20) and $820 \mathrm{~nm}(20$ $\mathrm{M}^{-1} \mathrm{~cm}^{-1}$ ) in $\mathrm{MeCN}$, respectively.

The X-ray structure of complex 1 was analyzed using a single crystal of $\left[\mathrm{NiP}[14] \mathrm{aneN}_{2} \mathrm{~S}_{2} \mathrm{Br}\right] \mathrm{ClO}_{4}$ that the water molecule was replaced by $\mathrm{Br}^{-}$ because it was fortunately obtained as a single crystal. As depicted in Fig. 1, the structure of the $\left[\mathrm{NiP}[14] \text { ane } \mathrm{N}_{2} \mathrm{~S}_{2} \mathrm{Br}\right]^{+}$cation part in the crystal was a distorted octahedron with one amino nitrogen $(\mathrm{Ni}-\mathrm{N}(1)=2.091(5) \AA)$, one pyridyl nitrogen $(\mathrm{Ni}-\mathrm{N}(3)=2.081(5) \AA)$, and two sulfurs 


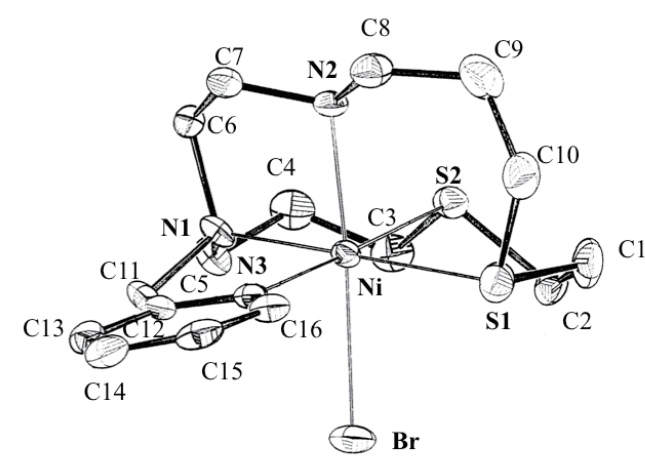

Figure 1. Crystal structure of a cation part of $\mathbf{1}$. Hydrogen atoms were omitted for clarity.

$(\mathrm{Ni}-\mathrm{S}(1)=2.437(2), \mathrm{Ni}-\mathrm{S}(2)=2.389(2) \AA)$ of $\mathrm{P}[14] \mathrm{aneN}_{2} \mathrm{~S}_{2}$ in the equatorial plane and with one amino nitrogen $(\mathrm{Ni}-\mathrm{N}(2)=2.107(5) \AA)$ and one $\mathrm{Br}^{-}(\mathrm{Ni}-\mathrm{Br}=2.580(1) \AA)$ at the axial positions. The Ni-Br distance, $2.580 \AA$, is somewhat longer than typical values for $\mathrm{Ni}-\mathrm{Br}$ lengths (2.536-2.572 $\AA),[14]$ although the other Ni-donor atom bond lengths are normal.

3.2 Electrochemistry and Chemical Reduction.

Cyclic voltammogram for complex $\mathbf{1}$ was measured in $\mathrm{MeOH}$ (Fig. 2(a)) and $\mathrm{MeCN}$ (Fig. 2(b)). That in $\mathrm{MeOH}$ exhibited only one

(a) $\mathrm{MeOH}$

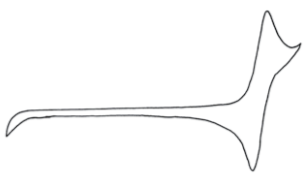

(b) $\mathrm{MeCN}$

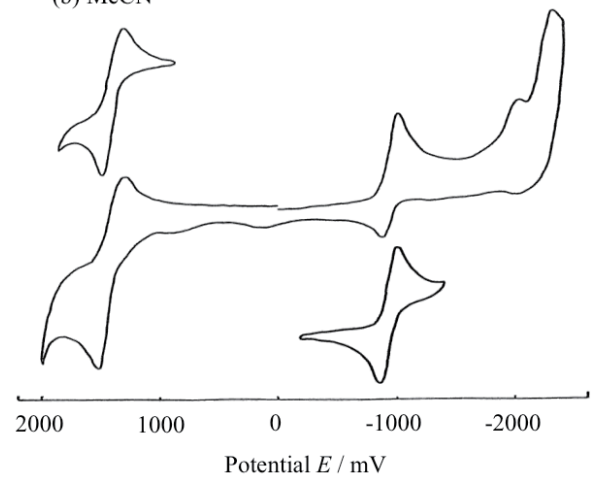

Figure 2. Cyclic voltammograms of $\mathbf{1}$ in (a) $\mathrm{MeOH}$ and (b) $\mathrm{MeCN}$

reversible wave assignable to the $\mathrm{Ni}^{2+/+}$ couple at $E_{1 / 2}=-920$ vs. SCE, and that in $\mathrm{MeCN}$ gave two reversible waves of $\mathrm{Ni}^{2+/+}$ and $\mathrm{Ni}^{3+/ 2+}$ couples at $E_{1 / 2}=$ -970 and $1350 \mathrm{mV}$ vs. SCE, respectively.

Addition of $\mathrm{NaBH}_{4}$ to $\mathrm{MeOH}$ solution of complex $\mathbf{1}$ at room temperature resulted in a drastic color change. After a few hours of the addition, the color was returned to that of the starting $\mathrm{Ni}$ (II) complex again. The absorption spectrum, as followed at $-20{ }^{\circ} \mathrm{C}$ under Ar, gave new two absorption bands at $350 \mathrm{~nm}(\mathrm{sh})$ and 510 $\mathrm{nm}$ ( $\varepsilon$ 130), which are assigned to the charge-transfer bands from ligand to metal and the d-d bands of $\mathrm{Ni}(\mathrm{I})$ complexes generated, respectively.

X-band ESR spectra of the Ni(I) complex in $\mathrm{MeOH}$ solution, which was reduced by $\mathrm{Na}_{2} \mathrm{~S}_{2} \mathrm{O}_{4}$, exhibited a axial pattern with $\mathrm{g}=2.01,2.11$, and 2.21 , indicating that a single unpaired electron lies on the $\mathrm{dx}^{2}-\mathrm{y}^{2}$ orbital of the nickel atom. Interestingly, that of the $\mathrm{Ni}(\mathrm{I})$ complex prepared by $\mathrm{NaBH}_{4}$ exhibited a rhombic pattern with $\mathrm{g}=$ $2.23,2.17,2.04$, showing the $\mathrm{dz}^{2}$ ground state (Fig. 3). Furthermore, the signal of $\mathrm{g}=2.04$ was split

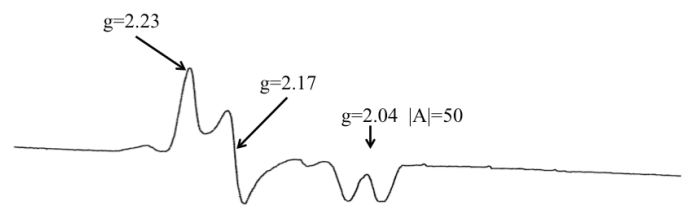

\begin{tabular}{|c|c|c|c|c|}
\hline 2800 & 3000 & 3200 & 3400 & 3600 \\
\hline
\end{tabular}

Figure 3. ESR spectrum of $\mathbf{1}$ reduced by $\mathrm{NaBH}_{4}$ in $\mathrm{MeOH}$.

in doublet $(A=50 \mathrm{G})$, suggesting that a nuclear spin of $I=1 / 2$ is located on the $\mathrm{dz}^{2}$ orbital of the $\mathrm{Ni}(\mathrm{I})$ center.[15] The fact that this hyperfine splitting was observed not in the use of $\mathrm{Na}_{2} \mathrm{~S}_{2} \mathrm{O}_{4}$ but in $\mathrm{NaBH}_{4}$ indicates that hydride anion is located on the $\mathrm{dz}^{2}$ orbital. Similar large doublet nuclear hyperfine splitting of $\mathrm{Ni}(\mathrm{I})-\mathrm{H}^{-}(\mathrm{A}=100$ $\mathrm{G})$ was observed in $\mathrm{HI}-\mathrm{Ni}(\mathrm{CO})_{4}$ system.[16]

Regrettably, the Ni(III) complex was not generated for complex 1, although the oxidation reactions with $\left[\mathrm{Ce}\left(\mathrm{NO}_{2}\right)_{3}\right]\left(\mathrm{NH}_{4}\right)_{2}$ and $\left(\mathrm{Et}_{4} \mathrm{~N}\right)_{3}\left[\mathrm{Fe}(\mathrm{CN})_{6}\right]$ were applied. The result indicates that it is difficult to chemically oxidize the Ni(II) complex 1 to the Ni(III) species.

\subsection{Biological Implications}

The ESR spectral feature of the product complex obtained by the reduction of complex $\mathbf{1}$ with $\mathrm{NaBH}_{4}$ is remarkably similar to that of the Ni-C Form in Thiocapsa roseopersicina hydrogenase. The ESR spectral evidence on the formation of hydrido-Ni(I) species opens a way to reveal the reaction mechanism at the active Ni site of the hydrogenases. Retention by bonding of a hydrogen atom on the central metal atom of the complexes 1 indicates that the $\mathrm{Ni}$ atom is surrounded with the $\mathrm{N}_{2} \mathrm{~S}_{2} \mathrm{~N}(\mathrm{py})$-pentacoordinate ligand of restricted backbone structure and controlled electronic structure of the central metal atom, or more specifically [NiP $\left.[14] \mathrm{aneN}_{2} \mathrm{~S}_{2} \mathrm{X}\right](\mathrm{X}$ : coordination site for hydride), may be profitable for artificial construction of an active $\mathrm{Ni}$ site of the enzyme. Further investigation related to these ligands is in progress. 


\section{CONCLUSION}

In order to construct the model complex of active sites in [FeNi]-hydrogenases that catalyze the reversible oxidation of dihydrogen,[1] the $\mathrm{Ni}(\mathrm{II})$ complex 1 was synthesized and the solution and crystal structures and electrochemical properties were investigated. The complex has been characterized by electronic absorption spectroscopy, cyclic voltammetry (CV), and X-ray structure analysis. Absorption spectra of the complex 1 demonstrated mainly to be 6 -coordinate in solutions. The solution structure of all $\mathrm{Ni}(\mathrm{II})$ complex corresponded well to the crystal structure. The redox potential of $\mathbf{1}$ exhibited considerably lower values and suggested that they can easily be controlled by appropriate selection of donor ligands. Reactions of the Ni(II) complex with reductants exhibited very interesting ESR spectral behaviors: In complex $\mathbf{1}$, the reaction with $\mathrm{NaBH}_{4}$ showed unique spectra which are characteristic for a rhombic pattern with a remarkably large hyperfine splitting at $g_{z}(A=50 \mathrm{G})$; this spectral pattern is quite similar to that of the $\mathrm{Ni}-\mathrm{C}$ species in Thiocapsa roseopersicina hydrogenase. Such a spectral feature of the large splitting was not observed in the reaction with $\mathrm{Na}_{2} \mathrm{~S}_{2} \mathrm{O}_{4}$. The above findings may indicate that the ESR spectrum detects the $\mathrm{Ni}(\mathrm{I})$ ion with an axially-bound hydride ion. We believe that the results obtained in this study will provide important information for further studies on the structure-function relationship of hydrogenases.

\section{REFERENCES}

[1] (a) J. J. G. Moura, M. Teixeira, I. Moura, and J. LeGall, "The Bioinorganic Chemistry of Nickel", Ed. by J. R. Lancaster, Jr., VCH Publishers: Deerfield Beach, FL, Chapter 9, pp 191-226 (1988). (b) N. R. Bastin, D. A. Wink, L. P. Wackett, D. J. Livingston, L. M. Jordan, J. Fox, W. H. Orme-Johnson, and C. T. Walsh, "The Bioinorganic Chemistry of Nickel", Ed. by J. R. Lancaster, Jr., VCH Publishers: Deerfield Beach, FL, Chapter 10, pp 227-247 (1988). (c) R. Cammack, V. M. Fernandez, and K. Schneider, "The Bioinorganic Chemisry of Nickel", Ed. by J. R. Lancaster, Jr., VCH Publishers: Deerfield Beach, FL, , Chapter 8, pp 167-190 (1988) and the references therein.

[2] (a) A. Volbeda, M. H. Charon, C. Piras, E. C. Hatchikian, M. Fery, and J. C. Fontecilla-Camps, Nature, 373, 580-587 (1995). (b) Y. Higuchi, T. Yagi, and N. Yasuoka, Structure, 5, 1671-1680 (1997).

[3] C. Bagyinya, J. P. Whitehead and M. J. Maroney, J. Am. Chem. Soc., 115, 3576-3585 (1993).

[4] J. P. Whitehead, R. J. Guibiel, C. Bagyinka, B. M. Hoffman and M. J. Maroney, J. Am. Chem. Soc., 155, 5629-5635 (1993).

[5] J. W. van der Zwaan, J. M. C. C. Coremans, E. C. M. Bouwens, and S. P. J. Albracht, Biochim.
Biophys. Acta, 1041, 101-110 (1990).

[6] T. L. James, D. M. Smith, and R. H. Holm, Inorg. Chem., 33, 4869-4877 (1994).

[7] C.-H. Lai, J. H. Reibenspies, and M. Y. Darensbourg, Angew. Chem. Int. Ed. Engl., 35, 2390-2393 (1996).

[8] S. Tanino, Z. Li, Y. Ohki and K. Tatsumi, Inorg. Chem., 48, 2358-2360 (2009).

[9] L. Siegfried and T. A. Kaden, Helv. Chim. Acta, 67, 29-38 (1984).

[10] Crystal data for 1: [Ni[14]ane $\left.\mathrm{N}_{2} \mathrm{~S}_{2} \mathrm{Br}\right](\mathrm{ClO})_{4}$, $\mathrm{C}_{16} \mathrm{H}_{27} \mathrm{NiBrClN}_{3} \mathrm{O}_{4} \mathrm{~S}_{2}$, M.W. 562.58, monoclinic, space group $C c(\# 9), a=17.747(1), b=7.0263(4)$, $c=17.5830(9) \mathrm{A}, \beta=98.649(5)^{\circ}, V=2166.3 \mathrm{~A}^{3}, Z$ $=4$, purple crystal $0.5 \times 0.5 \times 0.8 \mathrm{~mm}, D_{\text {calc }}=$ $1.725, F(000)=1152.0$, and $\mu=30.89 \mathrm{~cm}^{-1}$ $(\mathrm{MoK} \alpha), 4378$ reflections measured, final $R=$ 0.043 and $R_{w}=0.042$ for 3735 observed $\left[\left(I_{0}\right)>2 \sigma\left(I_{0}\right)\right]$ reflections.

[11] J. A. Ibes and W, C. Hamilton, "International Tables for X-ray Crystallography", Kynoch Birmingham, England, Vol. IV (1974).

[12] "teXan, Crystal Structure Analysis Package", Molecular Corporation, pp 1992 (1995).

[13] "MolEN, An International Structure Solution Procedure" Enraf Nonius, Delft, The Netherlands.

[14] L. Sacconi and F. Mani, "Comprehensive Coordination Chemistry Vol. 5" Ed. by G. Wilkinson, R. Gillad, and J. A. McCleverty, Pergamon Press, Oxford, London, pp 45-107 (1987).

[15] (a) A. G. Lappin and A. McAuley, Adv. Inorg. Chem., 32, 241-295 (1988). (b) J. C. Saleruno, "The Bioinorganic Chemistry of Nickel", Ed. by J. R. Lancaster, Jr., VCH Publishers: Deerfield Beach, FL, Chapter 3, pp 53-71 (1988).

[16] J. R. Morton and K. F. Preston, J. Chem. Phys., 81, 5775-5778 (1984).

(Received May 1, 2009; Accepted May 3, 2009) 